Article

\title{
Facilitated Chromium(VI) Transport across an Ionic Liquid Membrane Impregnated with Cyphos IL102
}

\author{
Francisco Jose Alguacil (D) \\ Centro Nacional de Investigaciones Metalurgicas (CSIC), Avda. Gregorio del Amo 8, 28040 Madrid, Spain; \\ fjalgua@cenim.csic.es
}

Academic Editor: Derek J. McPhee

Received: 10 June 2019; Accepted: 1 July 2019; Published: 2 July 2019

\begin{abstract}
Chromium(VI) is a well-known hazardous element, thus, its removal from aqueous sources is of a general concern. Among the technologies used for the removal of this type of toxic elements, liquid membranes are gaining in importance and the same has occurred with the use of ionic liquids, considered for many, due to their properties, as green solvents. Thus, the present work joined the three previous points, presenting an experimental study about the removal of chromium(VI) by the use of a liquid membrane operation which used the commercially available Cyphos IL102 ionic liquid as a carrier. The experimental variables included: the stirring speed applied to the feed and receiving solution (a key-parameter to gain maximum transport), acid, chromium(VI), sodium hydroxide and Cyphos IL102 concentrations in their various phases. Additionally, the performance of the present system was evaluated both against the presence of other metals in solution and other carriers. The experimental results confirmed that Cyphos IL102 is a good carrier for chromium(VI) transport and, thus, its removal from aqueous streams, and it also performed well in the presence of accompanying metals and against the performance of other commercially available carriers.
\end{abstract}

Keywords: chromium(VI); Cyphos IL102; membrane transport; recovery; ionic liquids; environment

\section{Introduction}

Ionic liquids, or green solvents, are a group of salts with various anion-cation compositions, which are liquids at a temperature below $100{ }^{\circ} \mathrm{C}$. Having some specific features, such as versatile solubility, non-volatility, physical and chemical stabilities, etc., make them a real alternative to hazardous volatile organic chemicals, especially solvents, though there are also serious concerns about the hazardousness of ionic liquids. Their applications do not end as substitutes of such solvents because, due to another important feature of these chemicals, i.e., the ability of their molecular structure to be tailored (task-specific ionic liquids) according to application requirements; they expand to catalysis, coordination chemistry, analytical chemistry, polymer materials, nanotechnologies, lithium-based batteries, etc., and also in separation processes of metals and other solutes [1-16].

In the case of the removal of metals present in aqueous solutions, chromium(VI) had found, and still has, a paramount interest due to its toxic and carcinogenic character [17]. Much had been written about the hazardousness of this element, upon ingesta, by humans, with a real episode of $\mathrm{Cr}(\mathrm{VI})$ contamination, during almost the 30 last year period of the 20th century, in a city located in the USA. As a result of this interest, researchers had developed a series of technologies in order to remove the element from the aqueous solutions containing in it. In many cases, ionic liquids have played a key-role in the success of the process, i.e., liquid-liquid extraction [18,19], ion exchange [20,21], adsorption [22,23], and liquid membranes [24,25], and very often the results obtained by the various authors are difficult to compare due to the different experimental conditions used, which, in the case of supported liquid membranes, included solid support, stirring speeds, carrier concentrations and type of organic diluent, etc. 
Considering the case of liquid membranes technology, and particularly supported liquid membranes operation mode, such membranes emerged as a real alternative to the liquid-liquid extraction processing in the field of separation technologies. Metal transport through liquid membranes is governed by kinetics parameters instead of chemical equilibrium between the organic and aqueous phases, characteristic for liquid-liquid extraction operation; this feature is of great advantage for the concentration of metals, in the receiving or strip phase, as compared with liquid-liquid extraction. Other characteristic features of liquid membranes are: low energy input, the use of small amounts of organic phases in the operation, the possibility of the treatment of solutions with a low metal concentration, and that the extraction and stripping stages occurred simultaneously. The liquid membrane operation combines the kinetics and selectivity of liquid-liquid extraction and the simplicity of the membrane diffusion processes [26,27].

The present investigation joined the three focal points briefly mentioned above: (i) ionic liquids, (ii) chromium(VI) toxicity and the necessity of its removal from aqueous streams, and (iii) the usefulness of supported liquid membranes in this environmental field of interest. Cyphos IL 102 (trihexyl tetradecylphosphonium bromide) was used to remove different metals from aqueous solutions [28-30], and it is used, in the present work, as a carrier, since no data were apparent available about its use in the removal of $\mathrm{Cr}(\mathrm{VI})$-bearing aqueous solution, broadening the knowledge about the performance of the Cyphos family of ionic liquids in this field, and also to continue the investigations that the present author is carrying out on the transport of $\mathrm{Cr}(\mathrm{VI})$ using different carriers. In the flat-sheet supported liquid membrane (FSSLM) technology used here, the carrier impregnates the membrane support, and different and important hydrodynamic and chemical operational variables affecting the transport of $\mathrm{Cr}(\mathrm{VI})$ across the membrane are investigated: the stirring speed applied to the feed and receiving phases, the composition of the feed, receiving and organic phases; also the selectivity of the system against the presence of other metals in the feed phase is evaluated. Further, the aim of this work, in terms of $\mathrm{Cr}(\mathrm{VI})$ transport, and better to compare the results obtained by different authors using different carriers (as it is said above, using different operational parameters), is to evaluate the performance of Cyphos IL102, against that of several industrial and potential Cr(VI) carriers, including a couple of ionic liquids, using the very same experimental conditions. In this investigation, these all important operational variables are deeply studied in order to optimize the transport operation of $\mathrm{Cr}(\mathrm{VI})$ from acidic liquid wastes, the investigation also aims to the evaluation of the mass transfer parameters.

\section{Results and Discussion}

Though there is not any specific information about the extraction of chromium(VI) by this ionic liquid, information about other systems [31,32], suggests that the transport of chromium(VI) through a supported liquid membrane impregnated with Cyphos IL102 can be attributed to the next reactions:

$$
\mathrm{R}_{3} \mathrm{R}^{\prime} \mathrm{P}^{+} \mathrm{Br}_{\mathrm{m}}^{-}+\mathrm{HCrO}_{4_{\mathrm{f}}}^{-} \rightarrow \mathrm{R}_{3} \mathrm{R}^{\prime} \mathrm{P}^{+} \mathrm{HCrO}_{4_{\mathrm{m}}}^{-}+\mathrm{Br}_{\mathrm{f}}^{-}
$$

In this, and successive equations, $\mathrm{f}, \mathrm{m}$, and $\mathrm{r}$ refer to the feed, membrane, and receiving phases, respectively. Accordingly with the above reaction, the chromium(VI) species react with the ionic liquid in the feed-membrane interface, releasing bromide ions to the feed phase, then in the membrane-receiving solution interface, chromate ions are released to the receiving phase with formation of $\mathrm{R}_{3} \mathrm{R}^{\prime} \mathrm{P}^{+} \mathrm{OH}^{-}$ species in the membrane phase:

$$
\mathrm{R}_{3} \mathrm{R}^{\prime} \mathrm{P}^{+} \mathrm{HCrO}_{4_{\mathrm{m}}}^{-}+2 \mathrm{OH}_{\mathrm{r}}^{-} \rightarrow \mathrm{R}_{3} \mathrm{R}^{\prime} \mathrm{P}^{+} \mathrm{OH}_{\mathrm{m}}^{-}+\mathrm{CrO}_{4_{\mathrm{m}}}^{2-}+\mathrm{H}_{2} \mathrm{O}
$$

In the feed-membrane interface the next reaction occurs:

$$
\mathrm{R}_{3} \mathrm{R}^{\prime} \mathrm{P}^{+} \mathrm{OH}_{\mathrm{m}}^{-}+\mathrm{Br}_{\mathrm{f}}^{-} \rightarrow \mathrm{R}_{3} \mathrm{R}^{\prime} \mathrm{P}^{+} \mathrm{Br}_{\mathrm{m}}^{-}+\mathrm{OH}_{\mathrm{f}}^{-}
$$


which regenerates the ionic liquid and Equation (1) is carried out again. When dichromate species are predominant in the feed phase (this occurs at chromium(VI) concentrations higher than $0.1 \mathrm{~g} / \mathrm{L}$ ), the next reactions also takes part (fully or partially if $\mathrm{HCrO}_{4}{ }^{-}$and $\mathrm{Cr}_{2} \mathrm{O}_{7}{ }^{2-}$ co-exists in the feed phase) in the transport process:

$$
\begin{gathered}
2 \mathrm{R}_{3} \mathrm{R}^{\prime} \mathrm{P}^{+} \mathrm{Br}_{\mathrm{m}}^{-}+\mathrm{Cr}_{2} \mathrm{O}_{7_{\mathrm{f}}}^{2-} \rightarrow\left(\mathrm{R}_{3} \mathrm{R}^{\prime} \mathrm{P}^{+}\right)_{2} \mathrm{Cr}_{2} \mathrm{O}_{7_{\mathrm{m}}}^{2-}+2 \mathrm{Br}_{\mathrm{f}}^{-} \\
\left(\mathrm{R}_{3} \mathrm{R}^{\prime} \mathrm{P}^{+}\right)_{2} \mathrm{Cr}_{2} \mathrm{O}_{7_{\mathrm{m}}}^{2-}+4 \mathrm{OH}_{\mathrm{r}}^{-} \rightarrow 2 \mathrm{R}_{3} \mathrm{R}^{\prime} \mathrm{P}^{+} \mathrm{OH}_{\mathrm{m}}^{-}+2 \mathrm{CrO}_{4_{\mathrm{m}}}^{2-}+\mathrm{H}_{2} \mathrm{O}
\end{gathered}
$$

Equations (3) and (1) follow again. There is the possibility that the transport process occurs via the transport of ion-paired species, thus, in the case of $\mathrm{HCrO}_{4}{ }^{-}$and in the feed-membrane interface:

$$
\mathrm{R}_{3} \mathrm{R}^{\prime} \mathrm{P}^{+} \mathrm{Br}_{\mathrm{m}}^{-}+\mathrm{H}_{\mathrm{f}}^{+}+\mathrm{HCrO}_{4_{\mathrm{f}}}^{-} \rightarrow\left(\mathrm{R}_{3} \mathrm{R}^{\prime} \mathrm{P}^{+} \mathrm{Br}^{-}\right)\left(\mathrm{H}_{2} \mathrm{CrO}_{4}\right)_{\mathrm{m}}
$$

whereas in the membrane-receiving solution interface:

$$
\left(\mathrm{R}_{3} \mathrm{R}^{\prime} \mathrm{P}^{+} \mathrm{Br}^{-}\right)\left(\mathrm{H}_{2} \mathrm{CrO}_{4}\right)_{\mathrm{m}}+2 \mathrm{OH}_{\mathrm{r}}^{-} \rightarrow \mathrm{R}_{3} \mathrm{R}^{\prime} \mathrm{P}^{+} \mathrm{Br}_{\mathrm{m}}^{-}+\mathrm{CrO}_{4 \mathrm{r}}^{2-}+2 \mathrm{H}_{2} \mathrm{O}
$$

which regenerates the ionic liquid and Equation (1) occurs again. Thus, the transport of chromium(VI) by this ionic liquid can be attributed to an anion-exchange process, Equations (1) and (4), being the corresponding stoichiometry dependent of the chromium(VI) concentration in the feed phase, and also/or by the transport of ion-paired species, Equation (6), and similarly in the case of the presence of $\mathrm{Cr}_{2} \mathrm{O}_{7}{ }^{2-}$ species in the feed solution.

\subsection{Influence of the Stirring Speed of the Feed Solution on Cr(VI) Transport}

In this batch liquid membrane operation, the stirring speed of the feed solution may have a key-role in the transport process, thus, this experimental variable was first investigated by the use of feed solutions containing $0.01 \mathrm{~g} / \mathrm{L} \mathrm{Cr}(\mathrm{VI})$ and $0.01 \mathrm{M} \mathrm{HCl}$ and water as the receiving phase, whereas the membrane phase was of $0.12 \mathrm{M}$ Cyphos IL102 in Solvesso 100. The results from these series of experiments were summarized in Table 1 , and the overall mass transfer coefficient $\mathrm{K}$ was calculated according to the next relationship (details about the equation are given in Section 3):

$$
\ln \frac{[\mathrm{Cr}]_{\mathrm{f}, \mathrm{t}}}{[\mathrm{Cr}]_{\mathrm{f}, 0}}=-\frac{\mathrm{A}}{\mathrm{V}} \mathrm{Kt}
$$

Table 1. Values of K at various stirring speeds of the feed phase.

\begin{tabular}{cc}
\cline { 2 - 3 } Stirring Speed, $\mathbf{~ m i n}^{-\mathbf{1}}$ & $\mathbf{K}, \mathbf{c m} / \mathbf{m i n}$ \\
\hline 400 & 0.12 \\
800 & 0.25 \\
1000 & 0.28 \\
1200 & 0.18 \\
\hline \multirow{2}{*}{ Membrane support. Durapore HVHP. Stirring speed of the receiving phase: $400 \mathrm{~min}^{-1}$. }
\end{tabular}

From the results shown in Table 1, it can be seen that the value of $\mathrm{K}$ increased with the increase of the stirring speed, applied to the feed phase, up to $1000 \mathrm{~min}^{-1}$ and then remained constant; thus, from $1000 \mathrm{~min}^{-1}$ the aqueous feed layer reached a minimum with maximized the value of the overall mass transfer coefficient, minimized the resistance to mass transfer, and apparently, the transport process was controlled by diffusion in the stagnant film of the feed solution. Thus, at $1000 \mathrm{~min}^{-1}$, a limiting value of $K$ is reached and:

$$
\mathrm{K}_{\lim }=\frac{\mathrm{D}_{\mathrm{Cr}, \mathrm{f}}}{\mathrm{d}_{\mathrm{f}}}
$$


$\mathrm{D}_{\mathrm{Cr}, \mathrm{f}}$ being the feed diffusion coefficient of the chromium-containing species (averaging $6 \times 10^{-4} \mathrm{~cm}^{2} / \mathrm{min}$ ) and $\mathrm{d}_{\mathrm{f}}$ the minimum thickness of the feed layer under the present experimental conditions. From this system, $\mathrm{d}_{\mathrm{f}}$ was estimated as: $2.1 \times 10^{-3} \mathrm{~cm}$. Table 1 showed that at a stirring speed of $1200 \mathrm{~min}^{-1}$ the value of $\mathrm{K}$ decreased, this is attributable to a displacement of carrier phase from the membrane pore by high turbulence caused by vigorous stirring.

Since:

$$
\mathrm{J}_{\lim }=\mathrm{K}_{\lim }[\mathrm{Cr}(\mathrm{VI})]_{\mathrm{f}, 0}
$$

A limiting flux value was estimated as $5.4 \times 10^{-8} \mathrm{~mol} / \mathrm{cm}^{2} \mathrm{~min}$. Under this limiting condition:

$$
\mathrm{J}_{\text {lim }}=\frac{\mathrm{D}_{\mathrm{m}}[\text { CyphosIL102] }}{\mathrm{nd}_{\mathrm{m}}}
$$

and the value of the membrane diffusion coefficient, $D_{m}$, was estimated as $5.6 \times 10^{-6} \mathrm{~cm}^{2} / \mathrm{min}$, considering $n=1$ (Cyphos IL 102 stoichiometric factor in Equation (1), and $d_{m}$ of $12.5 \times 10^{-3} \mathrm{~cm}$ (see Section 3). Furthermore, the diffusion coefficient of the chromium(VI) species in the bulk membrane phase, $D_{m, b}$, can be also estimated as:

$$
\mathrm{D}_{\mathrm{m}, \mathrm{b}}=\frac{\mathrm{D}_{\mathrm{m}} \tau^{2}}{\varepsilon}
$$

$\tau$ and $\varepsilon$ being the membrane tortuosity and porosity, respectively (see Section 3 ). Thus, $D_{m, b}$ was $2.1 \times 10^{-5} \mathrm{~cm}^{2} / \mathrm{min}$. The comparison of $D_{m}$ and $D_{m, b}$ values for the present system, showed that $D_{m}$ value is lower than that of $D_{m, b}$, this being attributed to the diffusional resistance caused by the membrane.

The stirring speed of $1000 \mathrm{~min}^{-1}$ in the feed phase was used in all the subsequent experiments.

\subsection{Influence of the Receiving Phase Composition and Stirring Speed on Chromium (VI) Transport}

Besides water, sodium hydroxide solutions were used to investigate their influence on chromium(VI) transport, and, more importantly, the recovery of the element in the receiving phase. In this series of experiments the same experimental conditions as above were maintained constant, whereas $0.1,0.5$ or $1 \mathrm{M} \mathrm{NaOH}$ solutions were used as receiving phases. The results from these experiments are shown in Table 2.

Table 2. Values of K using different receiving phases.

\begin{tabular}{ccc}
\hline Receiving Phase & $\mathbf{K}, \mathbf{c m} / \mathbf{m i n}$ & $\mathbf{a} \% \mathbf{C r}(\mathbf{V I})$ Recovered in the Receiving Phase \\
\hline Water & 0.28 & 13.4 \\
$0.1 \mathrm{M} \mathrm{NaOH}$ & 0.28 & 56.1 \\
$0.5 \mathrm{M} \mathrm{NaOH}$ & 0.28 & 58.3 \\
$1 \mathrm{M} \mathrm{NaOH}$ & 0.28 & 60.6 \\
\hline
\end{tabular}

Membrane support: Durapore HVHP. Stirring speed of the receiving phase: $400 \mathrm{~min}^{-1}$. a After $2 \mathrm{~h}$.

The composition of the receiving phase had no effect on the $\mathrm{K}$ value, but it had a remarkable influence in the case of the percentage of chromium(VI) recovered in the receiving phase, especially when sodium hydroxide solutions were used instead of water. From this Table it can be also concluded that the increase of the $\mathrm{OH}^{-}$concentration in the receiving solution had a negligible influence on $\mathrm{K}$ value. The independence of the metal transport on the $\mathrm{OH}^{-}$concentration might be an indication that in the present system the $\mathrm{R}_{3} \mathrm{R}^{\prime} \mathrm{P}^{+} \mathrm{OH}^{-}$species, Equations (2) and (5), did not contribute apparently to the transport process. Further transport experiments were conducted using a $0.5 \mathrm{M} \mathrm{NaOH}$ solution as receiving phase.

In the case of the investigation of the influence of the stirring speed applied to the receiving phase on $\mathrm{K}$ value, all the experimental conditions used above were fixed except the stirring speed of the receiving phase which was varied between 400 and $800 \mathrm{~min}^{-1}$. This experiments showed that 
the variation of the stirring speed in the above range, had a negligible effect both on the $\mathrm{K}$ value $(0.28 \mathrm{~cm} / \mathrm{min})$ and on the percentage of chromium recovered in the receiving phase $(58.3 \%$ and $58.6 \%$ for the stirring speeds of 400 and $800 \mathrm{~min}^{-1}$, respectively). Thus, $400 \mathrm{~min}^{-1}$ was selected throughout all further experiments conducted in this investigation.

\subsection{Influence of $\mathrm{HCl}$ Concentration in the Feed Solution on Cr(VI) Transport}

The effect of the acid concentration on chromium(VI) transport was evaluated at different $\mathrm{HCl}$ concentration ranging from 0.01 to $10 \mathrm{M}$. Table 3 summarized the results from these experiments.

Table 3. Influence of the $\mathrm{HCl}$ concentration in the feed phase on the $\mathrm{K}$ value.

\begin{tabular}{cc}
\hline $\mathbf{H C l}, \mathbf{M}$ & $\mathbf{K}, \mathbf{c m} / \mathbf{m i n}$ \\
\hline 0.01 & 0.28 \\
0.1 & 0.28 \\
0.5 & 0.27 \\
1 & 0.27 \\
2.5 & 0.25 \\
5 & 0.13 \\
10 & 0.04
\end{tabular}

Feed phase: $0.01 \mathrm{~g} / \mathrm{L} \mathrm{Cr}(\mathrm{VI})$ and $\mathrm{HCl}$. Stirring speed: $1000 \mathrm{~min}^{-1}$. Membrane phase: $0.12 \mathrm{M}$ Cyphos IL102 in Solvesso 100. Membrane support: Durapore HVHP. Receiving phase: $0.5 \mathrm{M} \mathrm{NaOH}$. Stirring speed: $400 \mathrm{~min}^{-1}$.

The results presented in Table 3 evidence that as the acidity of the aqueous feed phase increased, there is a marked decrease in chromium(VI) transport. Thus, from $\mathrm{HCl}$ concentrations above $2.5 \mathrm{M}$ Equation (1) has a negligible contribution to the metal transport; also, the increase of the $\mathrm{HCl}$ concentration is accompanied by an increase of I (ionic strength), and this increase has a negative influence on the transport of chromium(VI) by Cyphos IL102. Additionally, an increase in the ion concentrations, due to the increase of I, in the solution (crowding effect) may have an influence on a given system.

\subsection{Influence of the Initial Chromium(VI) Concentration in the Feed Phase on the Overall Mass Transfer Coefficient Value}

A range of experiments were conducted to investigate the effect that the initial chromium(VI) concentration in the feed solution had on the $\mathrm{K}$ value. The results from these experiments were shown in Figure 1, plotting $\ln \left([\mathrm{Cr}]_{\mathrm{f}, \mathrm{t}} /[\mathrm{Cr}]_{\mathrm{f}, 0}\right)$ versus time. In this Figure two zones can be defined. At longer period times, and from the beginning of the experiment in the case of the chromium concentrations of 0.01 and $0.05 \mathrm{~g} / \mathrm{L}$, a straight line was defined and the system responded well to Equation (8), with corresponding overall mass transfer coefficients values showed in Table 4 . It is shown that these values decreased as the initial chromium concentration increased in the feed solution. For each, chromium(VI) concentration the metal flux can be estimated as:

$$
\mathrm{J}=\mathrm{K}[\mathrm{Cr}(\mathrm{VI})]_{\mathrm{f}, 0}
$$

and the values were shown in Table 4 . It was seen that the flux value increased sharply with the increase of the initial metal concentration of the feed solution, and then seemed to became independent of the initial chromium(VI) concentration. The initial increase of the flux with the metal concentration was in accordance with that was expressed in Equation (13), whereas the trend to a constant flux value was attributable to a saturation of the membrane pores, resulting in a lower effective membrane area towards the metal transport. 


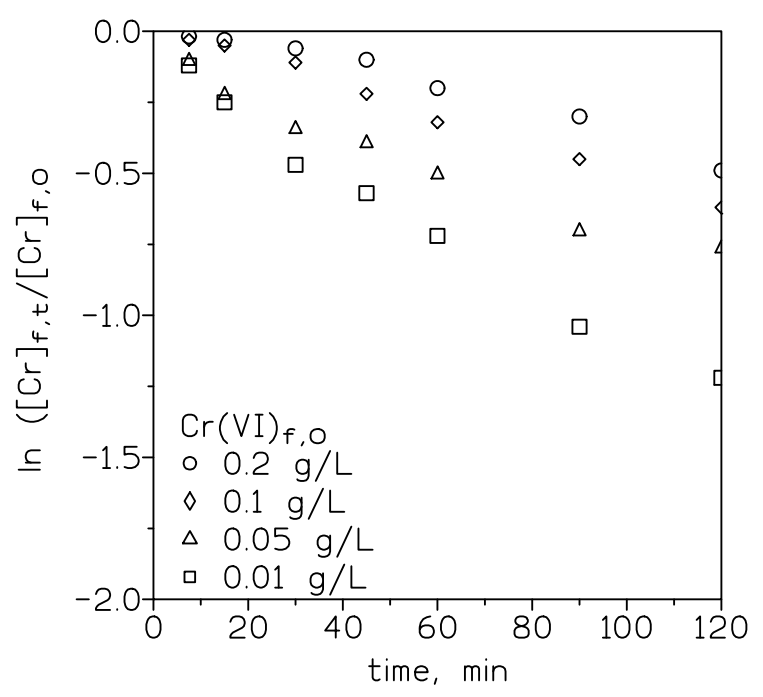

Figure 1. Influence of the initial chromium(VI) concentration in the feed solution on metal transport. Feed phase: $0.01 \mathrm{~g} / \mathrm{L} \mathrm{Cr}(\mathrm{VI})$ and $\mathrm{HCl}$. Stirring speed: $1000 \mathrm{~min}^{-1}$. Membrane phase: $0.12 \mathrm{M}$ Cyphos IL102 in Solvesso 100. Membrane support: Durapore HVHP. Receiving phase: $0.5 \mathrm{M} \mathrm{NaOH}$. Stirring speed: $400 \mathrm{~min}^{-1}$.

Table 4. Overall mass transfer values at various initial $\mathrm{Cr}(\mathrm{VI})$ concentrations.

\begin{tabular}{cccc}
\hline$(\mathbf{C r}(\mathbf{V I}))_{\mathbf{f}, \mathbf{0}}, \mathbf{g} / \mathbf{L}$ & $\mathbf{K}, \mathbf{c m} / \mathbf{m i n}$ & $\mathbf{J} \times \mathbf{1 0}^{\mathbf{7}}, \mathbf{m o l} / \mathbf{c m}^{\mathbf{2}} \mathbf{m i n}$ & $\begin{array}{c}\text { a \% } \mathbf{C r}(\mathbf{V I}) \text { Recovered in } \\
\text { the Receiving Phase }\end{array}$ \\
\hline 0.01 & 0.28 & 0.53 & 58.3 \\
0.05 & 0.21 & 2 & 57.0 \\
0.1 & 0.12 & 2.3 & 43.5 \\
0.2 & 0.07 & 2.7 & 21.1 \\
\hline
\end{tabular}

Experimental conditions as in Figure 1. ${ }^{\mathrm{a}}$ After $2 \mathrm{~h}$.

At short elapsed times and for chromium concentrations above $0.1 \mathrm{~g} / \mathrm{L}$, and from data presented in Figure 1, an induction period was observed. In these conditions, the metal transport is controlled by diffusion and Equation (8) is not valid, the next equation then must be considered:

$$
[\mathrm{Cr}]_{\mathrm{f}, \mathrm{t}}=[\mathrm{Cr}]_{\mathrm{f}, 0}-\frac{[\text { CyphosIL102 }]_{\mathrm{m}} \mathrm{D}_{\text {org }} \mathrm{A}}{\mathrm{nd}_{\mathrm{m}} \mathrm{V}}
$$

where $\mathrm{D}_{\text {org }}$ is the membrane diffusion coefficient, and $\mathrm{n}$ is the number of carrier molecules involved in chromium transport. $[\mathrm{Cr}]_{\mathrm{f}, \mathrm{t}}$ and $[\mathrm{Cr}]_{\mathrm{f}, 0}$ had the significance showed in Section 3.

Since from $0.1 \mathrm{~g} / \mathrm{L} \mathrm{Cr}(\mathrm{VI})$ in the aqueous solution, $\mathrm{Cr}_{2} \mathrm{O}_{7}{ }^{2-}$ becomes predominant in the feed phase, Equation (4) was only considered in chromium transport, and thus, $n=2$ in Equation (14). A plot of $[\mathrm{Cr}]_{\mathrm{f}, \mathrm{t}}$ versus $\mathrm{t}$ allowed $\mathrm{D}_{\mathrm{org}}$, to be estimated, which in the present case was $2.5 \times 10^{-5} \mathrm{~cm}^{2} / \mathrm{min}$, considering a carrier concentration of $0.12 \mathrm{M}$. It should be noted here, that $\mathrm{D}_{\text {org }}$ value is independent of the initial metal concentration in the feed phase, since this concentration term does not appeared in the extreme right term of Equation (14). Furthermore, the initial overall mass transfer coefficient, $\mathrm{K}_{0}$, can be estimated from the next relationship:

$$
\mathrm{K}_{0}=\frac{[\text { CyphosIL102 }]_{\mathrm{m}} \mathrm{D}_{\text {org }}}{[\mathrm{Cr}]_{\mathrm{f}, 0} \mathrm{nd}_{\mathrm{m}}}
$$

and $\mathrm{K}_{0}$ values were estimated as $6.3 \times 10^{-2}$ and $3.1 \times 10^{-2} \mathrm{~cm} / \mathrm{min}$ for the chromium concentrations of 0.1 and $0.2 \mathrm{~g} / \mathrm{L}$, respectively, and considering again a $0.12 \mathrm{M}$ Cyphos IL 102 concentration and $n=2$. 
Results showed in Table 4 also indicated that under the present experimental conditions, the percentage of chromium(VI) recovered in the receiving solution was dependent on the initial metal concentration in the feed phase.

\subsection{Influence of Carrier Concentration on Chromium(VI) Transport}

In this set of experiments the influence of the Cyphos IL102 concentration on metal transport was evaluated using carrier concentrations ranging from 0.003 to $0.12 \mathrm{M}$; as usual, the carrier was dissolved in Solvesso 100. Table 5 presents the data derived from the experiments.

Table 5. K values at various carrier concentrations.

\begin{tabular}{ccc}
\hline (Cyphos IL102), $\mathbf{M}$ & $\mathbf{K}, \mathbf{c m} / \mathbf{m i n}$ & $\mathbf{a}$ \% $\mathbf{C r}(\mathbf{V I})$ Recovered in the Receiving Phase \\
\hline 0.003 & 0.21 & 57.1 \\
0.007 & 0.23 & 58.8 \\
0.015 & 0.23 & 61.3 \\
0.03 & 0.24 & 59.2 \\
0.06 & 0.25 & 56.8 \\
0.12 & 0.28 & 58.3 \\
\hline
\end{tabular}

Feed phase: $0.01 \mathrm{~g} / \mathrm{L} \mathrm{Cr}(\mathrm{VI})$ and $\mathrm{HCl}$. Stirring speed: $1000 \mathrm{~min}^{-1}$. Membrane phase: $0.12 \mathrm{M}$ Cyphos IL102 in Solvesso 100. Membrane support: Durapore HVHP. Receiving phase: $0.5 \mathrm{M} \mathrm{NaOH}$. Stirring speed: $400 \mathrm{~min}^{-1}$. a After $2 \mathrm{~h}$.

From these result it was shown that the increase of the carrier concentration solution impregnating the membrane pores had a positive effect on metal transport, increasing the value of the overall mass transfer coefficient (and the percentage of metal transport) from $0.21(56.4 \%)$ to $0.28(70.5 \%) \mathrm{cm} / \mathrm{min}$ for the range of carrier concentration investigated. It is also shown in the table that the variation of these carrier concentrations had a negligible effect on the percentage of chromium recovered in the receiving solution.

\subsection{Contribution of Mass Transfer Resistances to the Overall Chromium(VI) Transport Process}

It is described in the literature [33], that the equilibrium and diffusional parameters involved in the transport process, can be combined in an equation of the form:

$$
\frac{1}{\mathrm{~K}}=\Delta_{\mathrm{f}}+\frac{\Delta_{\mathrm{m}}}{\mathrm{C}}
$$

where $\mathrm{C}$ is a parameter, involved in the extraction or transport process, which considers the extraction equilibrium constant or constants and the concentration of the species which participated within the process. $\Delta_{\mathrm{f}}$ and $\Delta_{\mathrm{m}}$ were the transport resistances in relation to diffusion by the feed boundary layer and the membrane, respectively.

In a transport process, the overall mass transfer resistance was the sum of the different resistances participating in the process and, thus, Equation (16) was rewritten as:

$$
\mathrm{R}=\mathrm{R}_{\mathrm{f}}+\mathrm{R}_{\mathrm{m}}
$$

Table 6 shows the contribution of these various resistances to the overall resistance. 
Table 6. Contribution of $\mathrm{R}_{\mathrm{f}}$ and $\mathrm{R}_{\mathrm{m}}$ to the overall chromium(VI) transport process.

\begin{tabular}{ccccc}
\hline Experimental Condition & $\mathbf{R}, \mathbf{m i n} / \mathbf{c m}$ & $\mathbf{R}_{\mathbf{f}}, \mathbf{m i n} / \mathbf{c m}$ & $\mathbf{\%}_{\mathbf{f}} \mathbf{0}^{\mathbf{0}}$ & ${\mathbf{~} \mathbf{o} \mathbf{R}_{\mathbf{m}}}^{\mathbf{0}}$ \\
\hline Stirring speed & $8.33-3.57$ & 3.57 & $43-100$ & $57-0$ \\
HCl concentration & $3.57-25$ & 3.57 & $100-14$ & $0-86$ \\
Cr(VI) concentration & $3.57-12.5$ & 3.57 & $100-29$ & $0-71$ \\
Carrier concentration & $4.76-3.57$ & 3.57 & $75-100$ & $25-0$ \\
\hline
\end{tabular}

In this Table, the percentage of the contribution of the fractional resistance to the overall process, $\% R_{f}{ }^{0}$ and $\% R_{m}{ }^{0}$ was estimated for each experimental condition, it was concluded that the diffusion by the aqueous feed boundary layer contributed in a major extend to the overall transport process.

\subsection{Transport of $\mathrm{Cr}(\mathrm{VI})$ from $\mathrm{Cr}(\mathrm{VI})-$ Metal Binary Solutions}

It seemed of interest to compare the performance of the present $\mathrm{Cr}(\mathrm{VI})$-Cyphos IL102 system when other metals were present in the feed solution. Thus, a series of tests was conducted using binary mixtures of $\mathrm{Cr}(\mathrm{VI})$ in the presence of $\mathrm{Cu}(\mathrm{II}), \mathrm{Fe}(\mathrm{III}), \mathrm{Co}(\mathrm{II}), \mathrm{Cr}(\mathrm{III}), \mathrm{Mn}(\mathrm{VII})$ (in the form of $\mathrm{MnO}_{4}^{-}$) and $\mathrm{Au}(\mathrm{III})$ (in the form of $\mathrm{AuCl}_{4}^{-}$). Then, the feed solution contained mixtures of the elements in an equimolar $1.9 \times 10^{-4} \mathrm{M}$ concentration in $0.01 \mathrm{M} \mathrm{HCl}$. The results from these series of experiments are shown in Table 7.

Table 7. $\mathrm{K}$ values in the transport of $\mathrm{Cr}(\mathrm{VI})$ from binary mixtures.

\begin{tabular}{ccc}
\hline System & $\mathbf{K}_{\mathbf{C r},} \mathbf{c m} / \mathbf{m i n}$ & $\mathbf{K}_{\mathbf{M}, \mathbf{c m} / \mathbf{m i n}}$ \\
\hline $\mathrm{Cr}(\mathrm{VI})$ & 0.28 & - \\
$\mathrm{Cr}(\mathrm{VI})-\mathrm{Cu}(\mathrm{II})$ & 0.24 & $\mathrm{Co}(\mathrm{II})$ not transported \\
$\mathrm{Cr}(\mathrm{VI})-\mathrm{Fe}(\mathrm{III})$ & 0.25 & $\mathrm{Fe}(\mathrm{III})$ not transported \\
$\mathrm{Cr}(\mathrm{VI})-\mathrm{Co}(\mathrm{II})$ & 0.22 & $\mathrm{Co}(\mathrm{II})$ not transported \\
$\mathrm{Cr}(\mathrm{VI})-\mathrm{Cr}(\mathrm{III})$ & 0.18 & ${ }^{\mathrm{C}} \mathrm{Cr}(\mathrm{III})$ not transported \\
$\mathrm{Cr}(\mathrm{VI})-\mathrm{Mn}(\mathrm{VII})$ & 0.15 & 0.65 \\
$\mathrm{Cr}(\mathrm{VI})-\mathrm{Au}(\mathrm{III})$ & 0.18 & 0.15 \\
\hline
\end{tabular}

Feed phase stirring speed: $1000 \mathrm{~min}^{-1}$. Membrane phase: $0.12 \mathrm{M}$ Cyphos IL102 in Solvesso 100. Membrane support: Durapore HVHP. Receiving phase: $0.5 \mathrm{M} \mathrm{NaOH}$. Stirring speed: $400 \mathrm{~min}^{-1}$. ${ }^{\text {a }}$ Result derived from a previous experiment using a single $\mathrm{Cr}(\mathrm{III})$ feed solution.

These results showed that chromium(VI) was transported quantitatively from other metals presents in the feed solution except from $\mathrm{Mn}(\mathrm{VII})$ and $\mathrm{Au}(\mathrm{III})$. Furthermore, $\mathrm{Mn}(\mathrm{VII})$ was transported preferably to $\mathrm{Cr}(\mathrm{VI})$ since $\beta_{\mathrm{Cr}(\mathrm{VI}) / \mathrm{Mn}(\mathrm{VII})}$ was estimated as 0.23 . $\beta$, or the separation factor, defines if two elements can be separated by means of a separation technology (liquid-liquid extraction, ion exchange, adsorption, liquid membranes). In the case of liquid membranes, the separation factor is defined as:

$$
\beta_{\mathrm{M} 1 / \mathrm{M} 2}=\frac{\mathrm{K}_{1}}{\mathrm{~K}_{2}}
$$

where $\mathrm{K}$ are the corresponding overall mass transfer coefficient values. Additionally, this relationship can be expressed in terms of metal permeability or $\mathrm{P}_{\mathrm{M}}$. Thus, if $\beta>1$ the metals can be separated, though this value gives no indication about the easiness of the separation.

The comparison of the $\mathrm{K}$ values presented in Table 7 with respect to the $\mathrm{K}$ value for the single transport of $\mathrm{Cr}(\mathrm{VI})$, indicated that this element was transported less favourably (lower $\mathrm{K}$ value) in the presence of the accompanying metal in the feed solution. This was a logical issue in the case of chromium(VI) transport in the presence of manganese(VII) and gold(III), since both elements were transported across the membrane containing Cyphos IL102, and there was a competition to bond with the ionic liquid, but it seemed less logical when other non-transportable elements are present in the feed phase. The explanation to this issue is the crowding or population effect that makes that the value of the overall mass transfer coefficient (or permeability coefficient) of a given metal decreases in the 
presence of other elements in the aqueous solution. This is not a generalized issue and its effect must be experimentally determined for each binary, ternary, etc., system.

Regarding the recovery of chromium in the receiving phase, experimental data indicated that in all the systems showed in Table 7, the percentage of $\mathrm{Cr}(\mathrm{VI})$ recovered was around $58 \%$ after $2 \mathrm{~h}$ running time, a value which compared extremely well with the yield (58.3\%) when single $\mathrm{Cr}(\mathrm{VI})$ was transported across the membrane impregnated with Cyphos IL102.

\subsection{Transport of $\mathrm{Cr}(V I)$ using Different Carriers}

Following the investigations on the system Cr(VI)-Cyphos IL102 and its performance on chromium(VI) transport, this section presents experimental data about the transport of the metal using the same membrane HVHP support impregnated with different carriers dissolved in Solvesso 100. It should be noted here, that all the carriers used in this experimentation are classified as industrial, that is, they are not mere laboratory-developed compounds. The best transport results were obtained when solutions of Amberlite LA2 and Aliquat 366 in Solvesso are used to impregnate the support, whereas the worst $\mathrm{K}$ values resulted from the use of Cyanex $471 \times$ and TBP as carriers for $\mathrm{Cr}(\mathrm{VI})$ transport. In the case of ionic liquid compounds, the series followed the order Aliquat $336>$ Cyphos IL101 > Cyphos IL102, whereas in the case of amines the order found was: secondary (Amberlite LA2) $>$ tertiary (Hostarex A324) > primary (Primene JMT). A point to consider here is that amines are potential precursors of ionic liquids when contacted with the suitable concentration of a mineral acid in an aqueous solution, these reactions resulting in compounds with $\mathrm{RNH}_{3}{ }^{+} \mathrm{X}^{-}, \mathrm{R}_{2} \mathrm{NH}_{2}{ }^{+} \mathrm{X}^{-}$, and $\mathrm{R}_{3} \mathrm{NH}^{+}$stoichiometries for primary, secondary, and tertiary amines, respectively, whereas $\mathrm{X}$ denotes the counter-anion of the mineral acid. In the case of neutral organic derivatives of the phosphoric acid, the results of Table 8 indicate that the apparent $\mathrm{Cr}(\mathrm{VI})$ transport order is: phosphine oxide $>$ phosphonic ester $>$ phosphoric ester.

Results from Table 8 also showed that the recovery of $\mathrm{Cr}(\mathrm{VI})$ in the receiving solution was very dependent of the carrier used to impregnate the membrane support, but in all the cases the recovery found was near or above 50\%, except in the case of DBBP, which was around $40 \%$.

Table 8. Transport of $\mathrm{Cr}(\mathrm{VI})$ using different carriers.

\begin{tabular}{cccc}
\hline Carrier & Active Group & $\mathbf{K}, \mathbf{c m} / \mathbf{m i n}$ & $\begin{array}{c}\text { a \% Cr(VI) Recovered in } \\
\text { the Receiving Phase }\end{array}$ \\
\hline Cyphos IL102 & $\mathrm{R}_{3} \mathrm{RP}^{+} \mathrm{Br}^{-}$ & 0.28 & 58.3 \\
DBBP & $(\mathrm{RO})_{2} \mathrm{RPO}$ & 0.08 & 39.4 \\
Cyanex 471× & $\mathrm{R}_{3} \mathrm{PS}$ & 0.05 & 52.4 \\
Cyanex 921 & $\mathrm{R}_{3} \mathrm{PO}$ & 0.09 & 50.6 \\
Cyphos IL101 & $\mathrm{R}_{3} \mathrm{R}^{\prime} \mathrm{P}^{+} \mathrm{Cl}^{-}$ & 0.30 & 50.1 \\
TBP & $\left(\mathrm{RO}_{3} \mathrm{PO}\right.$ & 0.04 & 51.8 \\
Primene JMT & $\mathrm{RNH}_{2}$ & 0.18 & 61.4 \\
Cyanex 923 & $\mathrm{R}_{3} \mathrm{PO}$ & 0.16 & 70.0 \\
Hostarex A324 & $\mathrm{R}_{3} \mathrm{~N}$ & 0.27 & 54.4 \\
Aliquiat 336 & $\mathrm{R}_{3} \mathrm{R}^{\prime} \mathrm{N}^{+} \mathrm{Cl}^{-}$ & 0.35 & 48.4 \\
Amberlite LA2 & $\mathrm{R}_{2} \mathrm{NH}$ & 0.37 & 51.3 \\
\hline
\end{tabular}

Feed phase: $0.01 \mathrm{~g} / \mathrm{L} \mathrm{Cr}(\mathrm{VI})$ in $0.01 \mathrm{M} \mathrm{HCl}$. Stirring speed: $1000 \mathrm{~min}^{-1}$. Membrane phase: HVHP support impregnated with $0.12 \mathrm{M}$ carrier in Solvesso 100. Receiving phase: $0.5 \mathrm{M} \mathrm{NaOH}$. Stirring speed: $400 \mathrm{~min}^{-1}$. a After 2 h. $R$ and $R^{\prime}$ different alkyl chains (see Table 9). 
Table 9. Chemical composition and source for the carriers.

\begin{tabular}{ccc}
\hline Carrier & Chemical Composition & Source \\
\hline Cyphos IL102 & Trihexyl tetradecylphosphonium bromide & Cytec Ind. \\
DBBP & Dibutyl butylphosphonate & Albright and Wilson \\
Cyanex 471X & Tri-isobutyl phosphine sulphide & Cytec Ind. \\
Cyanex 921 & Tri-n-octyl phosphine oxide & Cytec Ind. \\
Cyphos IL101 & Trihexyl tetradecylphosphonium chloride & Cytec Ind. \\
TBP & Tri-n-butyl phosphate & Fluka \\
Primene JMT & mixture of t-alkylprimary amines & Rohm and Haas \\
Cyanex 923 & mixture of tri-n-alkyl phosphine oxides & Cytec Ind. \\
Hostarex A 324 & Tri-iso-octylamine & Hoechst \\
Aliquiat 336 & Tri-octyl methylammonium chloride & Fluka \\
Amberlite LA2 & Secondary alkylamine & Fluka \\
\hline
\end{tabular}

\subsection{Transport of $C r(V I)$ under two Types of Liquid Membrane Operations}

The performance of the flat-sheet supported liquid membrane (FSSLM) was compared with other membrane technology named pseudo-emulsion membrane with strip dispersion (PEMSD), see Section 3. The experiments with the PEMSD technology were conducted using aqueous solutions containing $0.01 \mathrm{~g} / \mathrm{L}$ or $0.05 \mathrm{~g} / \mathrm{L} \mathrm{Cr}(\mathrm{VI})$ in $0.01 \mathrm{M} \mathrm{HCl}$ medium, and strip phases of $0.5 \mathrm{M} \mathrm{NaOH}$. The membrane support was of a HVHP support impregnated with a 0.007 M Cyphos IL102 in Solvesso 100 solution. The results derived from these experiments are summarized in Table 10.

Table 10. Transport of Cr(VI) using FSSLM and PEMSD technologies.

\begin{tabular}{ccc}
\hline Membrane Technology & $\mathbf{K}, \mathbf{c m} / \mathbf{m i n}$ & a $\%$ Cr(VI) Recovered in the Receiving Phase \\
\hline b FSSLM & 0.23 & 58.8 \\
b PEMSD & 0.22 & 95.9 \\
c PEMSD & 0.18 & 80.0 \\
\hline
\end{tabular}

${ }^{a}$ After 2 h. ${ }^{b}$ Feed phase: $0.01 \mathrm{~g} / \mathrm{L} \mathrm{Cr}(\mathrm{VI})$ in $0.01 \mathrm{M} \mathrm{HCl} .{ }^{\mathrm{c}}$ Feed phase: $0.05 \mathrm{~g} / \mathrm{L} \mathrm{Cr}(\mathrm{VI})$ in $0.01 \mathrm{M} \mathrm{HCl}$.

These results show that the change in the membrane technology did not altered the transport of $\mathrm{Cr}(\mathrm{VI})$ from the feed solution to the membrane phase. The most important feature of this PEMSD smart technology was that the percentage of $\mathrm{Cr}(\mathrm{VI})$ recovered in the receiving solution improved quite substantially (95.9\% against $58.8 \%$ for FSSLM). This undoubtedly was the result of the formation of the pseudo-emulsion phase between the organic and receiving phases, and the intimate contact between droplets of these two phases in the cell chamber, which favored the metal transfer from the $\mathrm{Cr}(\mathrm{VI})$-loaded organic solution to the receiving solution. Additionally, the concentration of the metal in the receiving solution increased with respect to that of the initial feed solution $(0.013 \mathrm{~g} / \mathrm{L}$ against 0.01 $\mathrm{g} / \mathrm{L}$, respectively) due to the variation of volumes used in this type the experimentation: $\mathrm{V}_{\text {feed }}=200 \mathrm{~mL}$ versus $\mathrm{V}_{\text {receiving }}=100 \mathrm{~mL}$. As it was expected, the $\mathrm{K}$ value of the more concentrated $\mathrm{Cr}(\mathrm{VI})$ solution $(0.05 \mathrm{~g} / \mathrm{L})$ decreased with respect to the value yielded with the $0.01 \mathrm{~g} / \mathrm{L}$ feed solution.

\subsection{Post-Treatment of the Cr(VI)-Bearing Receiving Solutions}

A post-treatment of the receiving solution containing chromium(VI) was derived from previous results in the literature [34]. Thus, a receiving solution containing circa $0.02 \mathrm{~g} / \mathrm{L} \mathrm{Cr}(\mathrm{VI})$ in $0.5 \mathrm{M} \mathrm{NaOH}$, was treated drop-wise with a $5 \mathrm{~g} / \mathrm{L}$ hydrazine sulphate solution; almost near the addition of the first drops, chromium(VI) reduced to the (III) oxidation state, this reduction was completed after the addition of $1 \mathrm{~mL}$ of the hydrazine solution to $100 \mathrm{~mL}$ of the alkaline $\mathrm{Cr}(\mathrm{VI})$ solution:

$$
4 \mathrm{CrO}_{4}^{2-}+7 \mathrm{H}_{2} \mathrm{O}+\frac{3}{2} \mathrm{~N}_{2} \mathrm{H}_{6}^{2-} \rightarrow 4 \mathrm{Cr}(\mathrm{OH})_{4}^{-}+7 \mathrm{OH}^{-}+\frac{3}{2} \mathrm{~N}_{2}
$$


Following this post-treatment, the still hazardous $\mathrm{Cr}(\mathrm{VI})$ receiving solution were transformed to the less toxic $\mathrm{Cr}(\mathrm{III})$ solution, facilitating its handling and possible storage; even, the yielding of a $\mathrm{Cr}(\mathrm{III})$-bearing pigment can be achieved by a $\mathrm{pH}$-controlled precipitation process.

\section{Materials and Methods}

Cyphos IL 102 (trihexyl tetradecylphosphonium bromide) was supplied from Cytec Ind. (Woodland Park, NJ, USA), whereas other extractants or carriers used in this work were obtained from different sources, these and their chemical compositions are shown in Table 9. Cyphos IL 102 and all those carriers were used as supplied by the manufacturer. Solvesso 100 (Iberia Chem., Madrid, Madrid Community, Spain) is an aromatic (99\%) organic diluent and also used as such. All other chemicals used were of G.R grade. The support used in this investigation was Durapore HVHP1400 with 75\% nominal porosity $(\varepsilon), 12.5 \times 10^{-3}$ thickness $\left(\mathrm{d}_{\mathrm{m}}\right), 0.45 \mu \mathrm{m}$ pore size and 1.67 tortuosity $(\tau)$.

The use of an organic diluent as Solvesso 100 was not a drawback for the present investigation because Solvesso 100 is an industrially available diluent which comply all the security norms. The use of the diluent was also useful because: (i) it serves to accommodate the range of the carrier concentrations to each particular use; in this type of separation process the cost of the carrier is the most important budget item, and it made little sense to use an excess of carrier concentration with no use; (ii) it allowed a decrease of the viscosity of the organic phase, as ionic liquids are particularly viscous and this property is a real drawback for any supported liquid membrane operation (like the use here or with hollow fiber modules), since it was a general and experimental finding norm, that an increase in the organic solution viscosity produced an immediate decrease in the transport of a given metal (as an exception to any rule, this result was no found in the present work due to the low range of Cyphos IL102 concentrations used in the experimentation).

Flat-sheet supported liquid membrane experiments were carried out in a two-compartment cell described elsewhere, as is the experimental procedure [35], whereas pseudo-emulsion membrane strip dispersion tests were conducted in the same cell, but in this case, in the receiving compartment, the receiving phase was substituted by a given volume of an organic phase similar to the one which impregnated the solid support and a given volume of the receiving phase. In the present investigation, the volumes of both the organic and the receiving solutions were of $100 \mathrm{~mL}$ each. The mixture of the two phases was contacted by agitation of the phases, the receiving phase being dispersed into the organic solution [36]. After stopping the agitation, the phases were separated by gravity, the time required for this separation being no more than $3 \mathrm{~min}$. This previous procedure was similar to that followed in hollow fiber modules using this strip phase dispersion operation [37,38].

All the above experiments were conducted at $20^{\circ} \mathrm{C}$.

Chromium(VI) and other metals in the aqueous solutions were analyzed by atomic absorption spectrometry, and the transport of the metals was computed using the expression showed in Equation (8) (see Section 2), for the case of $\mathrm{Cr}(\mathrm{VI})$. In this Equation (8), A is the area of the support used in this work $\left(11.3 \mathrm{~cm}^{-2}\right), \mathrm{V}$ is the volume of the feed phase $(200 \mathrm{~mL}), t$ is the elapsed time, and $[\mathrm{Cr}(\mathrm{VI})]_{\mathrm{f}, \mathrm{t}}$ and $[\mathrm{Cr}(\mathrm{VI})]_{\mathrm{f}, 0}$ are the chromium concentrations in the feed at time $\mathrm{t}$ and time 0 , respectively.

The percentage of chromium(VI) recovery in the receiving solution was calculated as:

$$
\%=\frac{\left[\operatorname{Cr}((\mathrm{VI})]_{\mathrm{r}, \mathrm{t}} \times 100\right.}{[\mathrm{Cr}(\mathrm{VI})]_{\mathrm{f}, 0}-[\mathrm{Cr}(\mathrm{VI})]_{\mathrm{f}, \mathrm{t}}}
$$

where $[\mathrm{Cr}(\mathrm{VI})]_{\mathrm{r}, \mathrm{t}}$ was the chromium concentration in the receiving solution at time $\mathrm{t}$.

\section{Conclusions}

Durapore HVHP1400 support impregnated with Cyphos IL102 ionic liquid is very efficient for the transport of $\mathrm{Cr}(\mathrm{VI})$ from $\mathrm{HCl}$ solutions. This effectiveness is of the same order than that was obtained with the similar Cyphos IL101 ionic liquid, as the values of the overall mass transfer coefficients resulted 
within the present investigation shown: 0.28 against $0.30 \mathrm{~cm} / \mathrm{min}$ for IL102 and IL101, respectively, whereas the recovery of $\mathrm{Cr}(\mathrm{VI})$ in the receiving solution is even higher (58.3\% for IL102, and $50.1 \%$ for IL101). At a stirring speed in the feed phase of $1000 \mathrm{~min}^{-1}$, a limiting value of $0.28 \mathrm{~cm} / \mathrm{min}$ for the overall mass transfer coefficient is obtained and the transport process is controlled by diffusion in the feed phase stagnant film. $\mathrm{Cr}(\mathrm{VI})$ is selectively transported from $\mathrm{HCl}$ solutions using a supported liquid membrane impregnated with Cyphos IL102 over $\mathrm{Cu}(\mathrm{II}), \mathrm{Co}(\mathrm{II}), \mathrm{Fe}(\mathrm{III})$ and $\mathrm{Cr}(\mathrm{III})$, allowing to the selective speciation of $\mathrm{Cr}(\mathrm{VI})-\mathrm{Cr}(\mathrm{III})$ from aqueous solutions. Against many transport systems, time dependent overall mass transfer coefficient is obtained at higher $\mathrm{Cr}(\mathrm{VI})$ concentrations $(0.1$ and $0.2 \mathrm{~g} / \mathrm{L}$ ) in the feed solutions and short running times. In these cases, initial values of the overall mass transfer coefficient are found to be $6.3 \times 10^{-2}$ and $3.1 \times 10^{-2} \mathrm{~cm} / \mathrm{min}$ for the above metal concentrations, respectively. Under various experimental conditions, stirring speed of the feed phase, $\mathrm{HCl}$ and $\mathrm{Cr}(\mathrm{VI})$ concentrations in the same phase and carrier concentration in the membrane phase, it is concluded that the diffusion by the aqueous feed boundary layer contributed in a major extend to the overall transport process. An advanced membrane technology such as PEMSD (pseudo-emulsion membrane strip dispersion), though does not improve the value of the overall mass transfer coefficient greatly increases the percentage of $\mathrm{Cr}(\mathrm{VI})$ recovered in the receiving solution. Further transport improvement of the overall process, by the use of hollow fiber modules, is expected.

Funding: This research received no external funding.

Acknowledgments: Author thanks to CSIC Agency (Spain) for support.

Conflicts of Interest: The author declares no conflict of interest.

\section{References}

1. Zheng, S.; Jiang, W.; Rashid, M.; Cai, Y.; Dionysiou, D.D.; O'Shea, K.E. Selective reduction of Cr(VI) in chromium, copper and arsenic (CCA) mixed waste streams using UV/TiO2 Photocatalysis. Molecules 2015, 20, 2622-2635. [CrossRef] [PubMed]

2. Alguacil, F.J.; García-Díaz, I.; López, F.A.; Rodríguez, O. Liquid-liquid extraction of cadmium(II) by TIOACl (tri-iso-octylammonium chloride) ionic liquid and its application to a TIOACl impregnated carbon nanotubes system. Rev. Metal. 2015, 51, e051. [CrossRef]

3. Navarro, R.; Saucedo, I.; Gallardo, V.; Guibal, E. Fe(III) recovery from HCl solutions using amberlite XAD-7 resin impregnated with a tetraalkyl phosphonium ionic liquid. Canadian, J. Chem. Eng. 2016, 94, 107-116. [CrossRef]

4. Alguacil, F.J.; López, F.A.; García-Díaz, I.; Rodriguez, O. Cadmium(II) transfer using (TiOAC) ionic liquid as carrier in a smart liquid membrane technology. Chem. Eng. Proc. Intensificatio 2016, 99, 192-196. [CrossRef]

5. Navarro, R.; Lira, M.A.; Saucedo, I.; Alatorre, A.; Avila, M.; Guibal, E. Amberlite XAD resins impregnated with ionic liquids for Au(III) recovery. Macromol. Symp. 2017, 374, 1600134. [CrossRef]

6. García-Díaz, I.; López, F.A.; Alguacil, F.J. Transport and recovery of indium(III) from aqueous solutions using pseudo-emulsion based hollow fiber strip dispersion with ionic liquid $\mathrm{RNH}_{3}{ }^{+} \mathrm{HSO}_{4}{ }^{-}$. Chem. Eng. Res. Des. 2017, 126, 134-141. [CrossRef]

7. Navarro, R.; Lira, M.A.; Saucedo, I.; Alatorre, A.; Guibal, E. Amberlite XAD-1180 impregnation with Cyphos IL101 for the selective recovery of precious metals from $\mathrm{HCl}$ solutions. Gold Bull. 2017, 50, 7-23. [CrossRef]

8. Alguacil, F.J. Non-dispersive extraction of gold(III) with ionic liquid Cyphos IL101. Sep. Purif. Technol. 2017, 179, 72-76. [CrossRef]

9. Zheng, Y.; Yu, Z.; Lin, F.; Guo, F.; Alamry, K.A.; Taib, L.A.; Asiri, A.M.; Wang, X. Sulfur-doped carbon nitride polymers for photocatalytic degradation of organic pollutant and eduction of $\mathrm{Cr}(\mathrm{VI})$. Molecules 2017, 22, 572. [CrossRef]

10. Selva, M.; Perosa, A.; Fiorani, G. Phosphonium salts and P-ylides. Organophosphorus Chem. 2018, 47, $157-211$. [CrossRef]

11. Alguacil, F.J.; Garcia-Diaz, I.; Escudero, E. Extraction of indium(III) from sulphuric acid medium by the ionic liquid (PJMTH ${ }^{+} \mathrm{HSO}_{4}^{-}$). Sep. Purif. Technol. 2019, 211, 764-767. [CrossRef] 
12. Nie, Y.; Hou, Q.; Li, W.; Bai, C.; Bai, X.; Ju, M. Efficient synthesis of furfural from biomass using $\mathrm{SnCl}_{4}$ as catalyst in ionic liquid. Molecules 2019, 24, 594. [CrossRef] [PubMed]

13. Svecova, L.; Papaïconomou, N.; Billard, I. Rh(III) aqueous speciation with chloride as a driver for its extraction by phosphonium based ionic liquids. Molecules 2019, 24, 1391. [CrossRef] [PubMed]

14. Nikolas Patsos, N.; Lewis, K.; Picchioni, F.; Kobrak, M.N. Extraction of acids and bases from aqueous phase to a pseudoprotic ionic liquid. Molecules 2019, 24, 894. [CrossRef] [PubMed]

15. Löwe, R.; Hanemann, T.; Hofmann, A. Polymerizable ionic liquids for solid-state polymer electrolytes. Molecules 2019, 24, 324. [CrossRef] [PubMed]

16. Jiang, Y.; Li, D.; Ma, X.; Jiang, F.; He, Q.; Qiu, S.; Li, Y.; Wang, G. Ionic liquid-ultrasound-based extraction of biflavonoids from selaginella helvetica and investigation of their antioxidant activity. Molecules 2018, 23, 3284. [CrossRef] [PubMed]

17. Luz, A.L.; Wu, X.; Tokar, E.J. Toxicology of inorganic carcinogens. Advances Molec. Toxicol. 2018, 12, 1-46. [CrossRef]

18. Mukherjee, K.; Saha, R.; Ghosh, A.; Saha, B. Chromium removal technologies. Res. Chem. Intermediates 2013, 39, 2267-2286. [CrossRef]

19. Kokare, A.; Suryavanshi, V.; Zanje, S.; Kore, G.; Waghmode, D.; Anuse, M. Development of a rapid and reliable liquid-liquid extractive method for the effective removal of chromium(VI) from electroplating waste water and tannery effluents. Russian J. Inorg. Chem. 2017, 62, 527-538. [CrossRef]

20. Dragan, E.S.; Humelnicu, D.; Dinu, M.V. Design of porous strong base anion exchangers bearing $N, N$-dialkyl 2-hydroxyethyl ammonium groups with enhanced retention of $\mathrm{Cr}(\mathrm{VI})$ ions from aqueous solution. React. Funct. Polym. 2018, 124, 55-63. [CrossRef]

21. Eldin, M.S.; Al-Bogami, A.S.; Aly, K.M.; Khan, Z.A.; Mekky, A.E.M.; Saleh, T.S.; Hakamy, A.A.W. Removal of chromium (VI) metal ions using Amberlite IRA-420 anion exchanger. Desalin. Water Treat. 2017, 60, 335-342. [CrossRef]

22. Alguacil, F.J.; Garcia-Diaz, I.; Lopez, F.; Rodriguez, O. Removal of Cr(VI) and Au(III) from aqueous streams by the use of nanoadsorption technology. Desalin. Water Treat. 2017, 63, 351-356. [CrossRef]

23. Vilardi, G.; Rodriguez-Rodriguez, J.; Miguel Ochando-Pulido, J.; Di Palma, L.; Verdone, N. Fixed-bed reactor scale-up and modelling for $\mathrm{Cr}(\mathrm{VI})$ removal using nano iron-based coated biomass as packing material. Chem. Eng. J. 2019, 361, 990-998. [CrossRef]

24. Alguacil, F.J.; Garcia-Diaz, I.; Lopez, F. Transport of Cr(VI) using an advanced membrane technology and $\left(\mathrm{PJMTH}^{+} \mathrm{NO}_{3}{ }^{-}\right)$ionic liquid derived from amine Primene JMT as green chemicals. Desalin. Water Treat. 2013, 51, 7201-7207. [CrossRef]

25. Meng, X.; Wang, C.; Ren, T.; Wang, L.; Wang, X.; Meng, X.; Wang, C.; Ren, T.; Wang, L.; Wang, X. Electrodriven transport of chromium (VI) using 1-octanol/PVC in polymer inclusion membrane under low voltage. Chem. Eng. J. 2018, 346, 506-514. [CrossRef]

26. De Agreda, D.; Garcia-Diaz, I.; López, F.A.; Alguacil, F.J. Supported liquid membranes technologies in metals removal from liquid effluents. Rev. Metal. Madrid 2011, 47, 146-168. [CrossRef]

27. Amini, M.; Rahbar-Kelishami, A.; Alipour, M.; Vahidi, O. Supported liquid membrane in metal ion separation: An overview. J. Membr. Sci. Res. 2018, 4, 121-135. [CrossRef]

28. Singh, R.; Mahandra, H.; Gupta, B. Solvent extraction studies on cadmium and zinc using Cyphos IL102 and recovery of zinc from zinc-platting mud. Hydrometallurgy 2017, 172, 11-18. [CrossRef]

29. Ola, P.D.; Matsumoto, M.; Kondo, K. Recovery of Fe and Mn from aqueous solution with solvent extraction and liquid membrane permeation using ionic liquids. Desalin. Water Treat. 2017, 75, 325-330. [CrossRef]

30. Singh, R.; Mahandra, H.; Gupta, B. Cyphos IL102 assisted liquid-liquid extraction studies and recovery of vanadium from spent catalyst. Min. Eng. 2018, 128, 324-333. [CrossRef]

31. Wieszczycka, K.; Wojciechowsk, A.; Krup, M.; Kordala-Markiewicz, R. Quaternary pyridinium ketoximes as zinc extractants from chloride solutions. J. Chem. Eng. Data 2013, 58, 3207-3215. [CrossRef]

32. Rodriguez de San Miguel, E.; Vital, X.; de Gyves, J. Cr(VI) transport via a supported ionic liquid membrane containing Cyphos IL101 as carrier: System analysis and optimization through experimental design strategies. J. Hazard. Mater. 2014, 273, 253-262. [CrossRef] [PubMed]

33. Comesaña, A.; Rodríguez-Monsalve, J.; Cerpa, A.; Alguacil, F.J. Non-dispersive solvent extraction with strip dispersión (NDSXSD) pertraction of Cd(II) in $\mathrm{HCl}$ médium using ionic liquid Cyphos IL101. Chem. Eng. J. 2011, 175, 228-232. [CrossRef] 
34. Alguacil, F.J.; Alonso, M.; Lopez, F.A.; Lopez-Delgado, A. Pseudo-emulsion membrane strip dispersion (PEMSD) pertraction of chromium(VI) using CYPHOS IL101 ionic liquid as carrier. Environ. Sci. Technol. 2010, 44, 7504-7508. [CrossRef] [PubMed]

35. Alguacil, F.J.; López-Delgado, A.; Alonso, M.; Sastre, A.M. The phosphine oxides Cyanex 921 and Cyanex 923 as carriers for facilitated transport of chromium (VI)-chloride aqueous solutions. Chemosphere 2004, 57, 813-819. [CrossRef] [PubMed]

36. Alguacil, F.J.; Alonso, M.; Lopez, F.; Lopez-Delgado, A. Uphill permeation of Cr(VI) using Hostarex A327 as ionophore by membrane-solvent extraction processing. Chemosphere 2008, 72, 684-689. [CrossRef] [PubMed]

37. Alguacil, F.J.; Alonso, M.; Lopez, F.A.; Lopez-Delgado, A. Application of pseudo-emulsion based hollow fiber strip dispersion (PEHFSD) for recovery of Cr(III) from alkaline solutions. Sep. Purif. Technol. 2009, 66, 586-590. [CrossRef]

38. Padilla, I.; Garcia-Diaz, I.; Urien, A.; Rodríguez, O.; Lopez, F.; Alguacil, F.J. Membrane-based extraction with strip/organic dispersion methodologies for metals removal and recovery from wastewaters. Desalin. Water Treat. 2012, 40, 282-297. [CrossRef]

Sample Availability: Not available. 